\title{
Characterization of Cr-Curcumin Complex by Differential Pulse Voltammetry and UV-Vis Spectrophotometry
}

\author{
Maurice O. Iwunze \\ Department of Chemistry, Morgan State University, Baltimore, MD 21251, USA \\ Correspondence should be addressed to Maurice O. Iwunze; maurice.iwunze@morgan.edu
}

Received 8 July 2013; Accepted 16 September 2013; Published 4 March 2014

Academic Editors: B. N. Barman, P. Janos, and A. Szemik-Hojniak

Copyright (C) 2014 Maurice O. Iwunze. This is an open access article distributed under the Creative Commons Attribution License, which permits unrestricted use, distribution, and reproduction in any medium, provided the original work is properly cited.

\begin{abstract}
Differential Pulse Voltammetry (DPV) and UV-Vis techniques were used in characterizing the complexation of chromium with curcumin. It was observed that chromium complexed with curcumin in a 1:3 ratio. The experimental values that were used to calculate this ratio were independently determined by the two techniques used. The values obtained from each technique agree with each other reasonably well, within limits of experimental error. The stability constant or formation constant, $K_{f}$, of the complex, $1.58 \times 10^{10}$, was determined using the Lingane equation and Gibb's free energy of formation was calculated as $-58.18 \mathrm{~kJ}$.
\end{abstract}

\section{Introduction}

The trivalent chromium which was used in this work is known to possess numerous health benefits, which include its enhancement of insulin action in regulating blood sugar level—critical factor in diabetic patients, weight loss, regulation of blood pressure, and cholesterol control [1-7]. In its use in weight loss, chromium picolinate, $\mathrm{Cr}(\mathrm{Pc})_{3}$, is generally used [8-11], although it has been seriously criticized about its effectiveness [12]. However, $\mathrm{Cr}(\mathrm{Pc})_{3}$ has been used to augment the chromium intake through dietary products [9]. On the other hand, curcumin, a phytochemical, has been known to exhibit many beneficial health effects including its anticarcinogenic [13-15] and antioxidative [16-21] activities. The internet is replete with enormous information and advertisement about using these chemicals as supplements for a better life. It is therefore anticipated that a complex formed by this mineral, $\mathrm{Cr}$, and the phytochemical, curcumin, should have greater beneficial health effect. The physicochemical and stability study of this complex should therefore be a good candidate to study and characterize. This is the theme of this work.

\section{Experimental}

2.1. Chemicals. Certified chromic nitrate was obtained from Fisher Scientific. 98\% pure curcumin and 98\% pure tetramethylammonium bromide (used as supporting electrolyte), were obtained from Acros Organics. Analytical reagent grade of DMSO was obtained from Aldrich Chemicals.

\subsection{Instruments}

Electrochemical. All electrochemical experiments were conducted using a three-electrode system comprising of the working electrode $(1.0 \mathrm{~mm}$ diameter) Glassy Carbon Electrode (GCE), obtained from Cypress Systems, a wound platinum wire as the counter electrode, and a commercial calomel electrode as the reference electrode which was obtained from Fisher Scientific. The reaction was carried out in a 1-compartment electrochemical cell. A computer-controlled electrochemical analyzer system supplied by Cypress Systems, Model CS-10190, was used to obtain the requisite voltammograms of the Cr-Curcumin complex.

The polisher, Metaserv 200, a brown polishing cloth, to resurface the electrode and 0.05 micron $\gamma$-aluminum powder, used in conjunction with the polishing cloth, were obtained from Buehler Ltd.

UV-Vis Absorptiometry. All UV-Vis spectra were obtained from Cary spectrophotometer, model IE, supplied by Varian Analytical Instruments Co. using a two-sided $3.5 \mathrm{~mL}$ cuvette. 
<smiles>COc1cc(/C=C/C(=O)CC(=O)/C=C/c2ccc(O)c(OC)c2)ccc1O</smiles><smiles>COc1cc(/C=C/C(=O)C/C(O)=C/Cc2ccc(O)c(OC)c2)ccc1O</smiles>
diketo form<smiles>COc1cc(/C=C/C(=O)C/C(O)=C/Cc2ccc(O)c(OC)c2)ccc1O</smiles>

Figure 1: The chemical structures of curcumin.

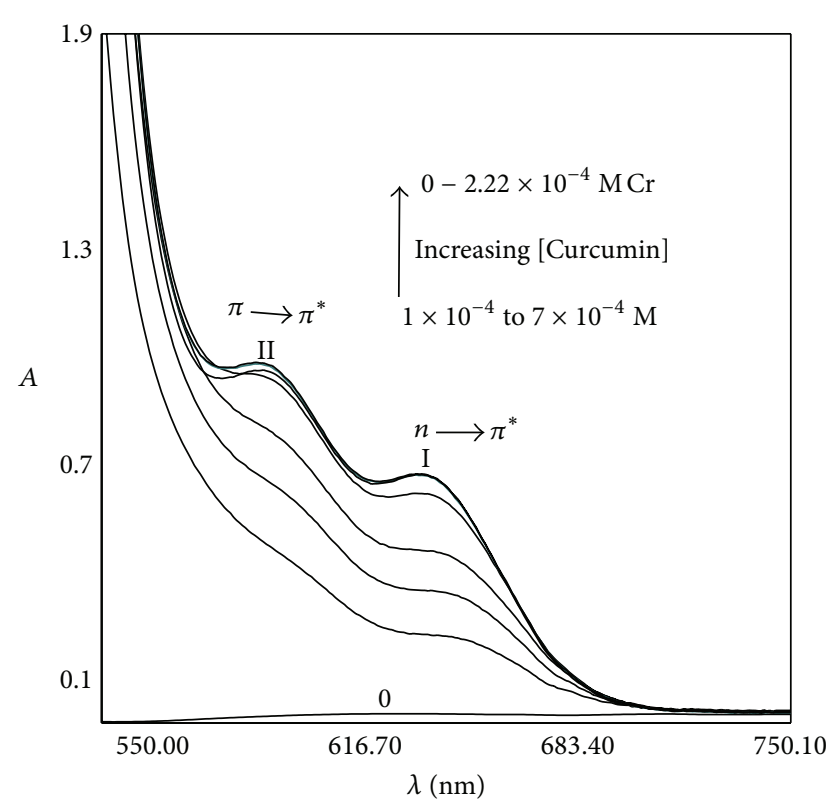

Figure 2: The UV-Vis spectra of $\mathrm{Cr}^{3+}$ and Cr-curcumin complex at constant $[\mathrm{Cr}]$.

\subsection{Methodology}

Electrochemical. Aliquots of stock solutions of curcumin, chromium, and tetramethylammonium bromide, TMAB, were pipetted into nine different $10.0 \mathrm{~mL}$ volumetric flasks and diluted to the fiduciary mark with neat dimethyl sulfoxide, DMSO. However flask number one contains all but curcumin. Upon dilution the resulting concentration of chromium was $2.0 \times 10^{-3} \mathrm{M}$ and that of curcumin varied from $1.467 \times 10^{-3} \mathrm{M}$ to $8.802 \times 10^{-3} \mathrm{M}$. The concentration of TMAB which was used as supporting electrolyte was constant in all the solutions at $0.15 \mathrm{M}$. Each solution was subsequently transferred into an electrochemical cell and scanned from $-100 \mathrm{mV}$ to $-800 \mathrm{mV}$ and their voltammogram was obtained. Being a DPV experiment, the $E_{1 / 2}$ was taken at the peak of the voltammogram, consistent with the usual electrochemical protocol. A triplicate scan for each solution was made and an

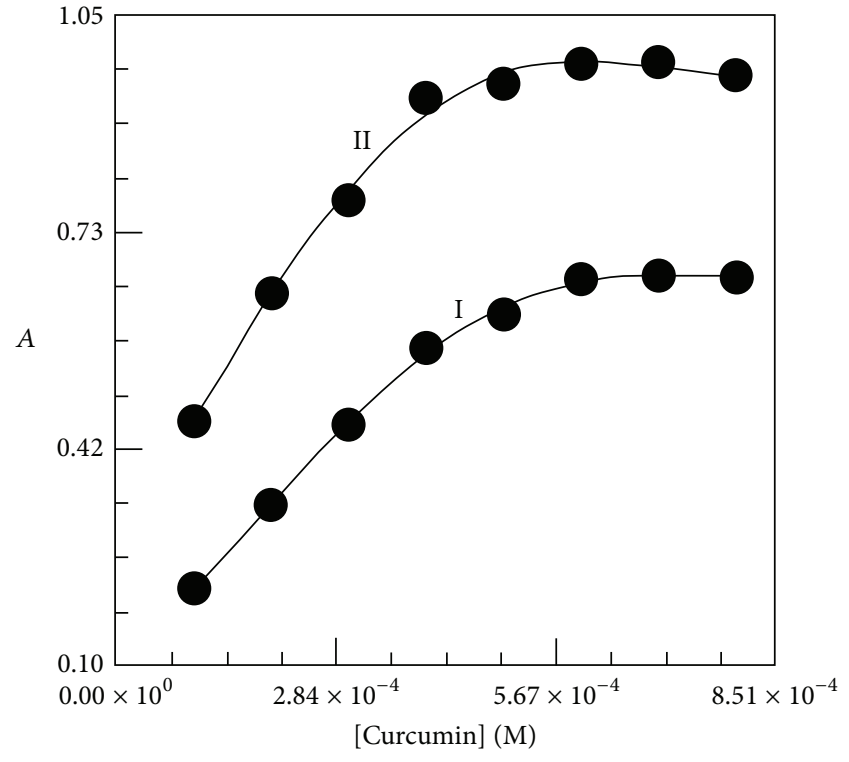

FIgure 3: The UV-Vis absorbance of Cr-curcumin complex at constant $\left[\mathrm{Cr}^{3+}\right]$ of $2.22 \times 10^{-4}$.

average of the $E_{1 / 2}$ was taken. After each scan the electrode surface was renewed by polishing.

$U V$-Vis Absorptiometry. The same process for preparing the solutions for electrochemical experiments was followed in the UV-Vis experiments except that the concentration of chromium was kept constant at $2.22 \times 10^{-4} \mathrm{M}$ and the curcumin concentration varied from $1.0 \times 10^{-4}$ to $8.0 \times 10^{-4}$ and the solutions contained no TMAB. The solutions were scanned from $750 \mathrm{~nm}$ to $500 \mathrm{~nm}$. All the reagents were used as received and the measurements were performed at room temperature, $25 \pm 0.2^{\circ} \mathrm{C}$.

\section{Results and Discussion}

Curcumin, a 1,3-diketo compound, exists in several tautomer forms. The most common ones are the diketo and the ketoenol forms. The keto-enol form has two equivalent keto-enol 


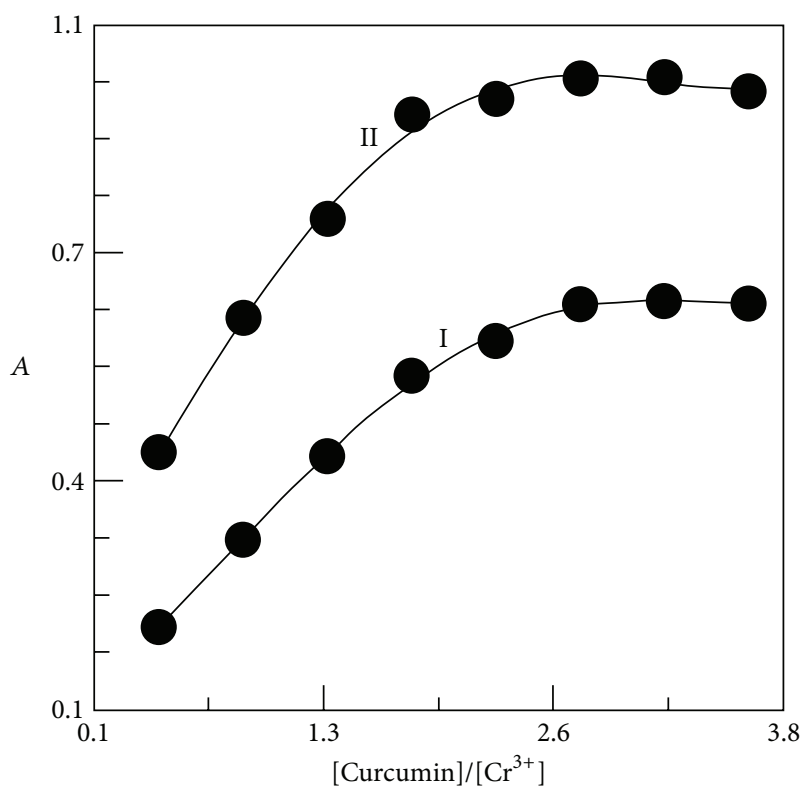

FIgURE 4: The UV-Vis absorbance of Cr-curcumin complex versus the molar ratio of $\mathrm{Cr}^{3+}$ and curcumin.

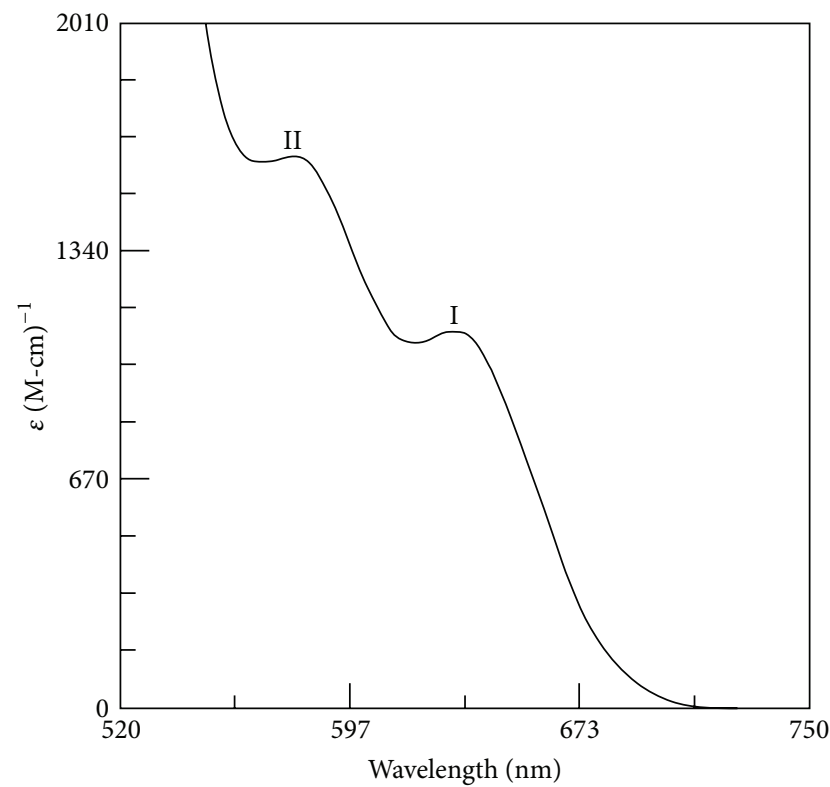

FIGURE 5: The UV-Vis absorbance of Cr-curcumin complex [curcumin] of $6 \times 10^{-4} \mathrm{M}$.

isomers ( $\mathrm{a}$ and $\mathrm{b}$ ). These are shown in Figure 1. It has been observed by other workers that in solution between $\mathrm{pH} 1$ and the neutral $\mathrm{pH}$ the predominant isomer of curcumin is the keto-enol tautomer ( $\mathrm{a}$ and $\mathrm{b}$ ) [22-28] which rapidly deprotonates $[26,28]$.

3.1. UV-Vis Spectrophotometry. We show in Figure 2 the UVVis spectra of the $\mathrm{Cr}$ and the Cr-Curcumin complexes. As can be seen two distinct peaks were observed. The peak observed at $573 \mathrm{~nm}$ is assigned to $\pi \rightarrow \pi^{*}$ transition

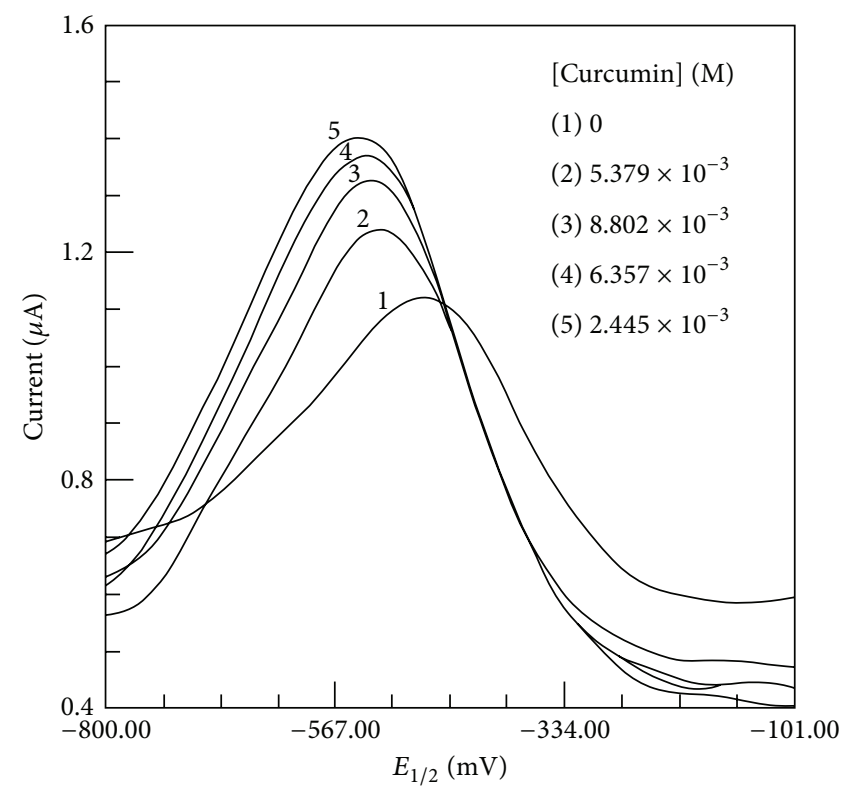

FIGURE 6: The voltammograms of $\mathrm{Cr}^{3+}$ and $\mathrm{Cr}$-curcumin complex.

and the peak at $665 \mathrm{~nm}$ is assumed to be due to the $n \rightarrow$ $\pi^{*}$ trasition. It is also seen that the $\mathrm{Cr}^{3+}$ has little or no absorption at the complex absorption wavelenghts. Figure 3 shows the plot of absorbance of the complex as a function of the ligand (curcumin) concentration for the bands observed, I and II. The bands, respectively, show increase in absorbance as the concentration of curcumin increases and reached a plateau when a full complexation is reached. This is what is expected of any complexation reaction. In Figure 4 we show the absorbance as a function of the molar ratio of chromium and curcumin. As can be seen, the two bands plateau upon full complexation. From this figure we obtained the stoichiometric coefficient of chromium to curcumin in the ratio of $1: 2.7 \approx 1: 3$ for the two bands, respectively. For the determination of the molar absorptivity, $\varepsilon$, of the complex, the concentration of the ligand that resulted in maximum complexation, $6 \times 10^{-4}$, was used. Given in Figure 5 is the spectrum of $6 \times 10^{-4} \mathrm{M}$. The observed absorbance was plotted as function of wavelength. Using this we determined the molar absorptivity of bands I and II. These are 632/M-cm and $1.625 \times 10^{3} / \mathrm{M}-\mathrm{cm}$ for bands I and II, respectively.

3.2. Electrochemical. For a reaction denoted as $\mathrm{M}^{m+}+n \mathrm{~L}$ $\rightarrow(\mathrm{ML} n)^{m+}$, where $\mathrm{M}$ is a metal with a charge of $m^{+}$and $\mathrm{L}$ is a neutral ligand with a stoichiometric coefficient of $n$, the voltammetric half wave potential is known to shift more negatively as more ligand is added to the solution. Lingane [29] derived equation (1) to explain this phenomenon:

$$
\Delta E_{1 / 2}=\frac{R T}{n F} \ln K_{d}-p \frac{R T}{n F} \ln [X] \text {. }
$$

In this equation $\Delta E_{1 / 2}$ is the difference between the half wave potential for the reduction of the metal ion and that of the complex, respectively. $R, T$ are the universal gas 


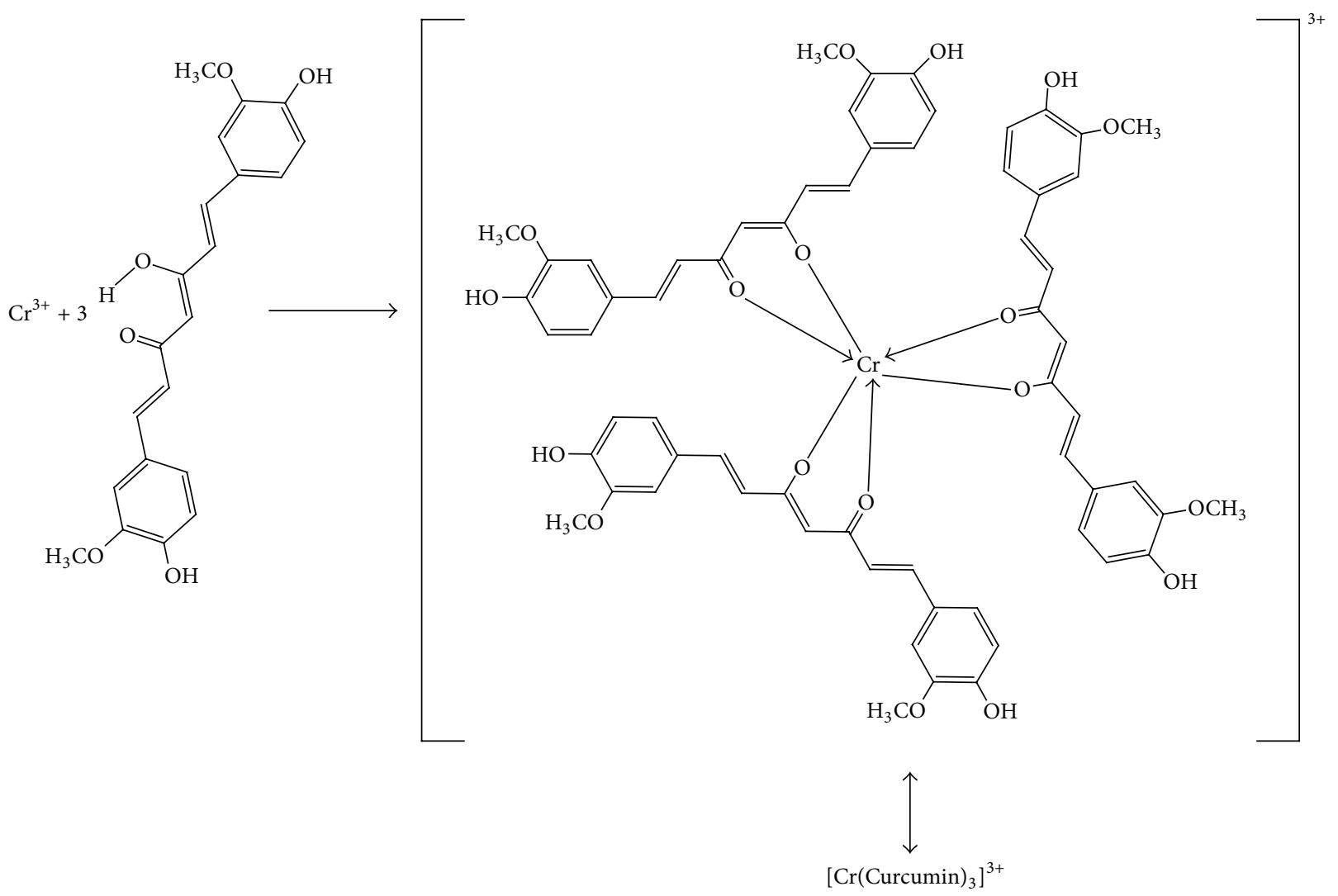

SCHEME 1

constant and absolute temperature, respectively. $n$ and $F$ are the number of electrons involved in the reaction and Faraday constant, respectively. The value of $n$ is taken as 3. $K_{d}$ is the dissociation constant of the complex and $[X]$ is the concentration of the ligand. This equation has been applied successfully by other workers for the determination of stability constant and the stoichiometric coefficient of a ligand in a complexometric reaction [30-34]. In this work the respective half wave potentials of the reduction of chromium and the chromium-curcumin complex were determined by DPV. The obtained voltammograms are shown in Figure 6.

It can be seen, as stated above, that the voltammogram of the complex shifts cathodically as the ligand concentration is increased. As expected a straight line was obtained as per equation (1) when $\Delta E_{1 / 2}$ is plotted against the logarithm of [curcumin]; see Figure 7. This plot gives a slope of $-2.303 p$ from which the value of $p$ was calculated as $3.4 \approx 3$ in good agreement with the value obtained by spectrophotometry. The intercept gives a value that is proportional to $K_{d} . K_{f}$ was subsequently determined since $K_{d}=1 / K_{f}$. The value of $K_{f}$ thus determined is $1.58 \times 10^{10} / \mathrm{M}$.

We determined Gibb's free energy of formation, $\Delta G_{f}$ using

$$
\Delta G_{f}=-\mathrm{RT} \ln K_{f}
$$

The value thus determined is $\Delta G_{f}=-58.18 \mathrm{~kJ}$.

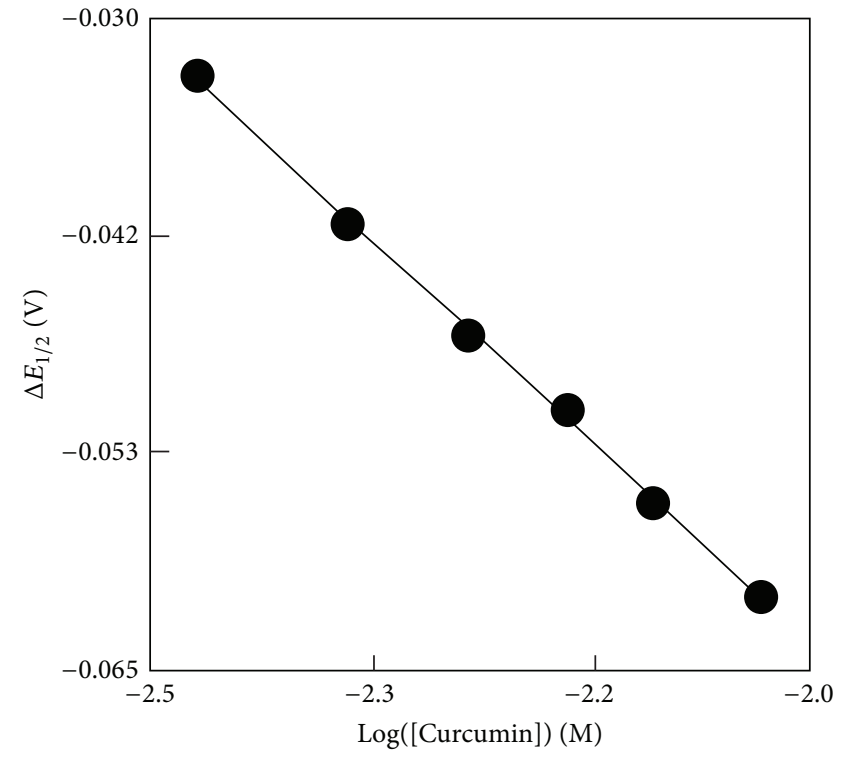

Figure 7: The plot of $\Delta E_{1 / 2}$ of Cr-curcumin complex versus the log, ([Curcumin]).

This high value of $K_{f}$ and the corresponding high negative of $\Delta G_{f}$ values indicate a very favorable and spontaneous formation of the complex with great stability. The observed parameters for this complexation reaction are given in Table 1. 
TABLE 1: The observed parameters of Cr-curcumin complex.

\begin{tabular}{lcc}
\hline Parameter & Value & Unit \\
\hline Number of ligands & 3 & \\
Molar absorptivity, $\varepsilon$ & 632 & $(\mathrm{M}-\mathrm{cm})^{-1}$ \\
$\quad$ Band I & $1.62 \times 10^{3}$ & $(\mathrm{M}-\mathrm{cm})^{-1}$ \\
$\quad$ Band II & $1.58 \times 10^{10}$ & $\mathrm{M}^{-1}$ \\
Formation constant, $K_{f}$ & -58.18 & $\mathrm{~kJ}$ \\
Free energy of formation, $\Delta G_{f}$ & \\
\hline
\end{tabular}

We give in Scheme 1 the reaction and plausible structure of the complex based on the determined parameters. The proposed structure of this complex is consistent with what other workers have proposed [23].

\section{Conflict of Interests}

The author hereby declares that there is no conflict of interests regarding the publication of this paper.

\section{Acknowledgment}

The author is grateful to the Chemistry Department of Morgan State University for its support for this work.

\section{References}

[1] W. T. Cefalu and F. B. Hu, "Role of chromium in human health and in diabetes," Diabetes Care, vol. 27, no. 11, pp. 2741-2751, 2004.

[2] J. Higdon, V. J. Drake, and R. A. Anderson, "Micronutrients: LPI research Newsletter," 2007, http://www.lpi.oregonstate .edu/infocenter/minerals/chromium.

[3] NIH Office of Dietary Supplements, "Chromium," http://ods.od .nih.gov/factsheet/Chromium.

[4] J. S. Striffler, J. S. Law, M. M. Polansky, S. J. Bhathena, and R. A. Anderson, "Chromium improves insulin response to glucose in rats," Metabolism, vol. 44, no. 10, pp. 1314-1320, 1995.

[5] W. Mertz, "Chromium in human nutrition: a review," Journal of Nutrition, vol. 123, no. 4, pp. 626-633, 1993.

[6] The University of Maryland Medical Center, "Chromium," http://www.umm.edu/altmed/articles/chromium.

[7] Drugs.com, "Chromium Picolinate," http://www.drugs.com/ $\mathrm{mtm} /$ chromium-icolinate.htm.

[8] WebMD, "Find a Vitamin or Supplement," http://www.webmd .com/vitaminssupplements/incgredientmono-932-CHROMIUM.aspx.

[9] M. H. Pittler and E. Ernst, "Dietary supplements for bodyweight reduction: a systematic review," American Journal of Clinical Nutrition, vol. 79, no. 4, pp. 529-536, 2004.

[10] M. H. Pittler, C. Stevinson, and E. Ernst, "Chromium picolinate for reducing body weight: meta-analysis of randomized trials," International Journal of Obesity, vol. 27, no. 4, pp. 522-529, 2003.

[11] G. W. Evans and T. D. Bowman, "Chromium picolinate increases membrane fluidity and rate of insulin internalization," Journal of Inorganic Biochemistry, vol. 46, no. 4, pp. 243-250, 1992.

[12] M. S. Mozaffari, R. Abdelsayed, J. Y. Liu, H. Wimborne, A. ElRemessy, and A. El-Marakby, "Effects of chromium picolinate on glycemic control and kidney of the obese zucker rat," Nutrition and Metabolism, vol. 6, article 51, 2009.

[13] K. Krishnaswamy and K. Polasa, "Nonnutrients and cancer prevention," ICMR Bulletin, vol. 31, pp. 1-9, 2001.

[14] Alternative Medicine Alert, "AnticancerPotential of Tumeric," 2003, http://www.thepowerhour.com/curmin/tumeric.

[15] W.-H. Chan and H.-J. Wu, "Protective effects of curcumin on methylglyoxal-induced oxidative DNA damage and cell injury in human mononuclear cells," Acta Pharmacologica Sinica, vol. 27, no. 9, pp. 1192-1198, 2006.

[16] F. Dai, W.-F. Chen, B. Zhou, L. Yang, and Z.-L. Liu, "Antioxidative effects of curcumin and its analogues against the freeradical-induced peroxidation of linoleic acid in micelles," Phytotherapy Research, vol. 23, no. 9, pp. 1220-1228, 2009.

[17] F. Dai, W.-F. Chen, B. Zhou, L. Yang, and Z.-L. Liu, "Antioxidative effects of curcumin and its analogues against the freeradical-induced peroxidation of linoleic acid in micelles," Phytotherapy Research, vol. 25, no. 11, p. 1736, 2011.

[18] O.-S. Baek, O.-H. Kang, Y.-A. Choi et al., "Curcumin inhibits protease-activated receptor-2 and -4-mediated mast cell activation," Clinica Chimica Acta, vol. 338, no. 1-2, pp. 135-141, 2003.

[19] B. B. Aggarwal, A. Kumar, and A. C. Bharti, "Anticancer potential of curcumin: preclinical and clinical studies," Anticancer Research, vol. 23, no. 1, pp. 363-398, 2003.

[20] M. Iqbal, S. D. Sharma, Y. Okazaki, M. Fujisawa, and S. Okada, "Dietary supplementation of curcumin enhances antioxidant and phase II metabolizing enzymes in ddY male mice: possible role in protection against chemical carcinogenesis and toxicity," Pharmacology and Toxicology, vol. 92, no. 1, pp. 33-38, 2003.

[21] W.-H. Chan, C.-C. Wu, and J.-S. Yu, "Curcumin inhibits UV irradiation-induced oxidative stress and apoptotic biochemical changes in human epidermoid carcinoma A431 cells," Journal of Cellular Biochemistry, vol. 90, no. 2, pp. 327-338, 2003.

[22] F. Payton, P. Sandusky, and W. L. Alworth, "NMR study of the solution structure of curcumin," Journal of Natural Products, vol. 70, no. 2, pp. 143-146, 2007.

[23] Y.-M. Song, J.-P. Xu, L. Ding, Q. Hou, J.-W. Liu, and Z.-L. Zhu, "Syntheses, characterization and biological activities of rare earth metal complexes with curcumin and 1,10-phenanthroline5,6-dione," Journal of Inorganic Biochemistry, vol. 103, no. 3, pp. 396-400, 2009.

[24] I. Stankov, "Curcumin," in Proceedings of the Chemical and Technical Assessment 61st Joint FAO/WHO Expert Committee on Food Additives, 2004.

[25] H. Kunkely and A. Vogler, "Photooxidation of N,N'-bis(3,5di-tert.-butylsalicylidene)-1,2-diamino hexane-manganese(III) chloride (Jacobsen catalyst) in chloroform," Inorganic Chemistry Communications, vol. 4, no. 12, pp. 692-694, 2001.

[26] S. V. Jovanovic, S. Steenken, C. W. Boone, and M. G. Simic, "H-atom transfer is a preferred antioxidant mechanism of 
curcumin," Journal of the American Chemical Society, vol. 121, no. 41, pp. 9677-9681, 1999.

[27] B. Zebib, Z. Mouloungui, and V. Noirot, "Stabilization of curcumin by complexation with divalent cations in glycerol/water system," Bioinorganic Chemistry and Applications, vol. 2010, Article ID 292760, 8 pages, 2010.

[28] H. H. Tønnesen, M. Másson, and T. Loftsson, "Studies of curcumin and curcuminoids. XXVII. Cyclodextrin complexation: solubility, chemical and photochemical stability," International Journal of Pharmaceutics, vol. 244, no. 1-2, pp. 127-135, 2002.

[29] J. J. Lingane, "Interpretation of the polarographic waves of complex metal ions," Chemical Reviews, vol. 29, no. 1, pp. 1-35, 1941.

[30] Y. Kumar, A. Garg, and R. Pandey, "Polarographic reduction of curcumin at dropping mercury electrode," International Journal of Pharmacy and Pharmaceutical Sciences, vol. 4, no. 2, pp. 314318, 2012.

[31] G. W. Luther III, T. F. Rozan, A. Witter, and B. Lewis, "Metalorganic complexation in the marine evironment," Geochemical Transactions, vol. 2, pp. 65-74, 2001.

[32] W. C. Hoyle and T. M. Thorpe, "Topics in chemical instrumentation: XCVII. Pulse polarography: a series of student experiments," Journal of Chemical Education, vol. 55, no. 5, pp. A229A233, 1978.

[33] H. Bilinski, R. Huston, and W. Stumm, "Determination of the stability constants of some hydroxo and carbonato complexes of $\mathrm{pb}(\mathrm{II}), \mathrm{cu}(\mathrm{II}), \mathrm{cd}(\mathrm{II})$ and $\mathrm{zn}(\mathrm{II})$ in dilute solutions by anodic stripping voltammetry and differential pulse polarography," Analytica Chimica Acta, vol. 84, no. 1, pp. 157-164, 1976.

[34] R. Ernst, H. E. Allen, and K. H. Mancy, "Characterization of trace metal species and measurement by trace metal stability constants by electrochemical techniques," Water Research, vol. 9, no. 11, pp. 969-979, 1975. 

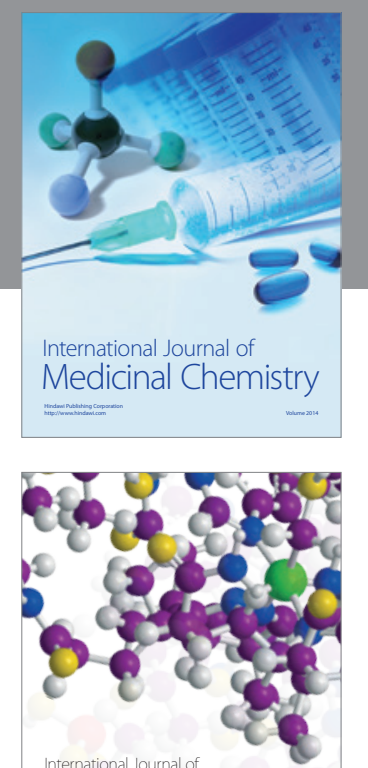

\section{Carbohydrate} Chemistry

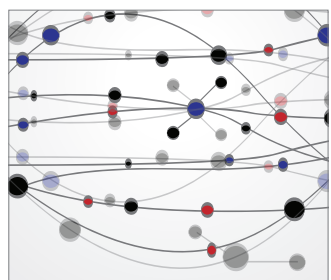

The Scientific World Journal
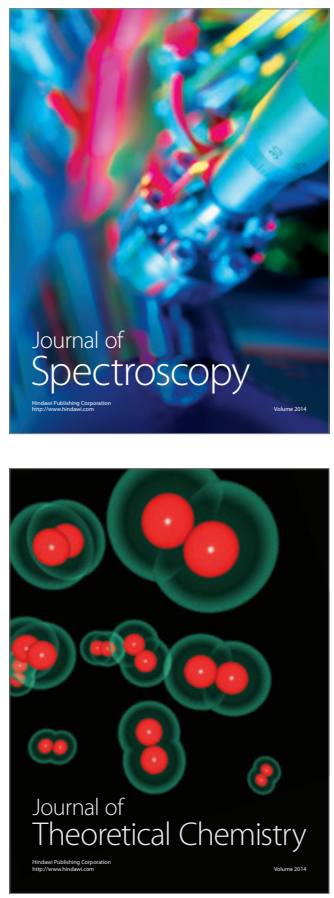
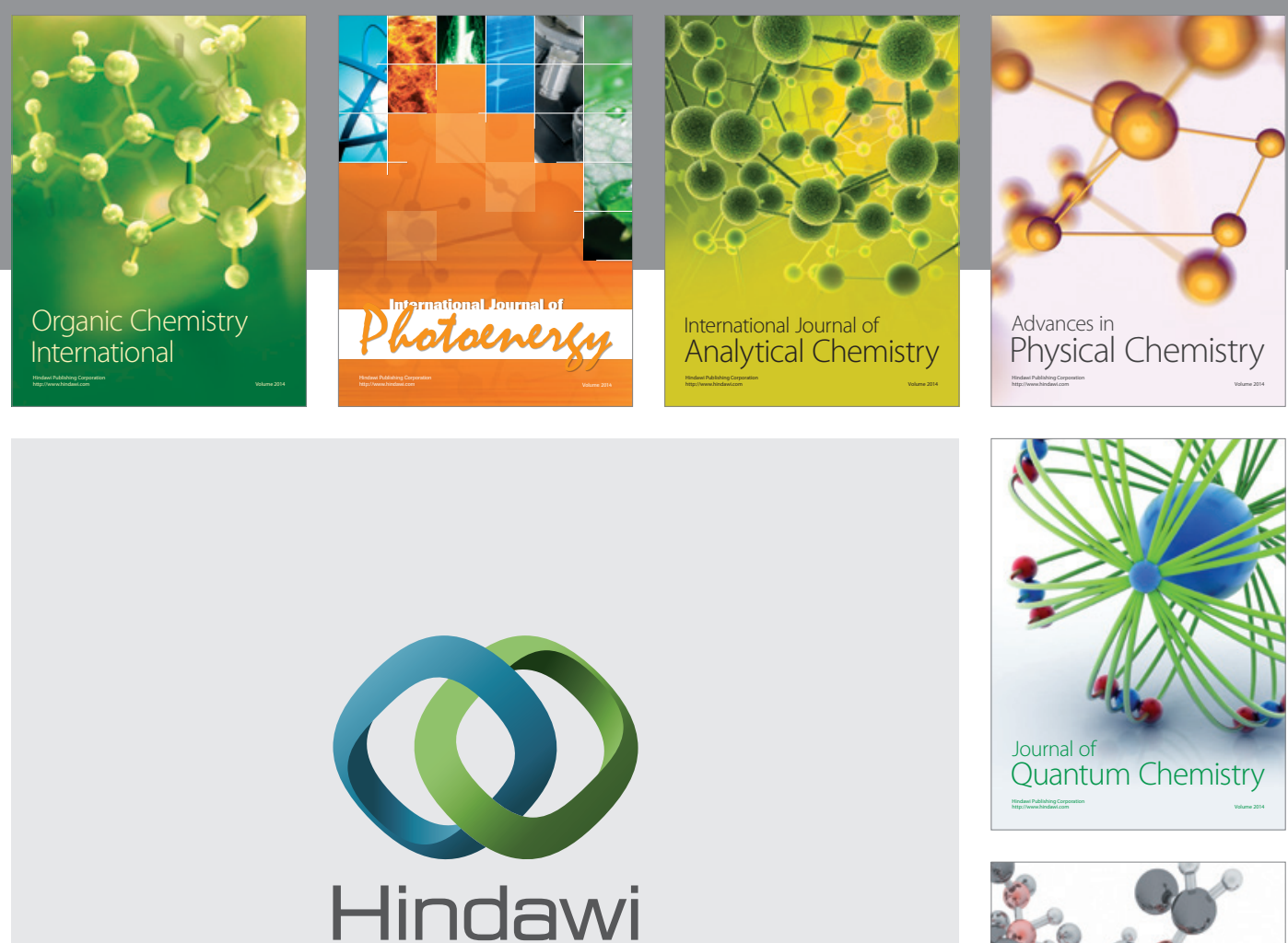

Submit your manuscripts at

http://www.hindawi.com

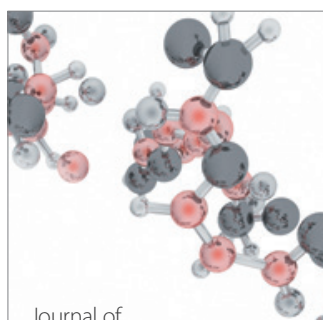

Analytical Methods

in Chemistry

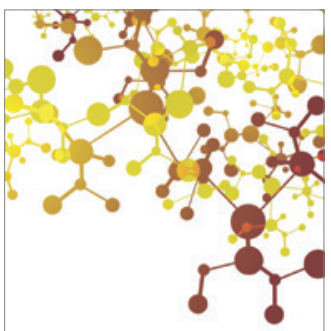

Journal of

Applied Chemistry

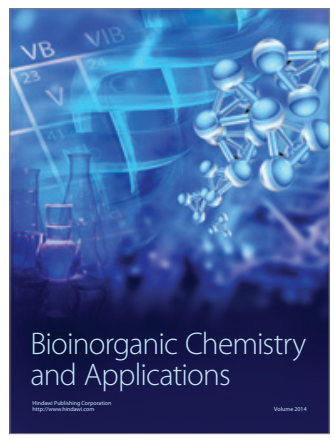

Inorganic Chemistry
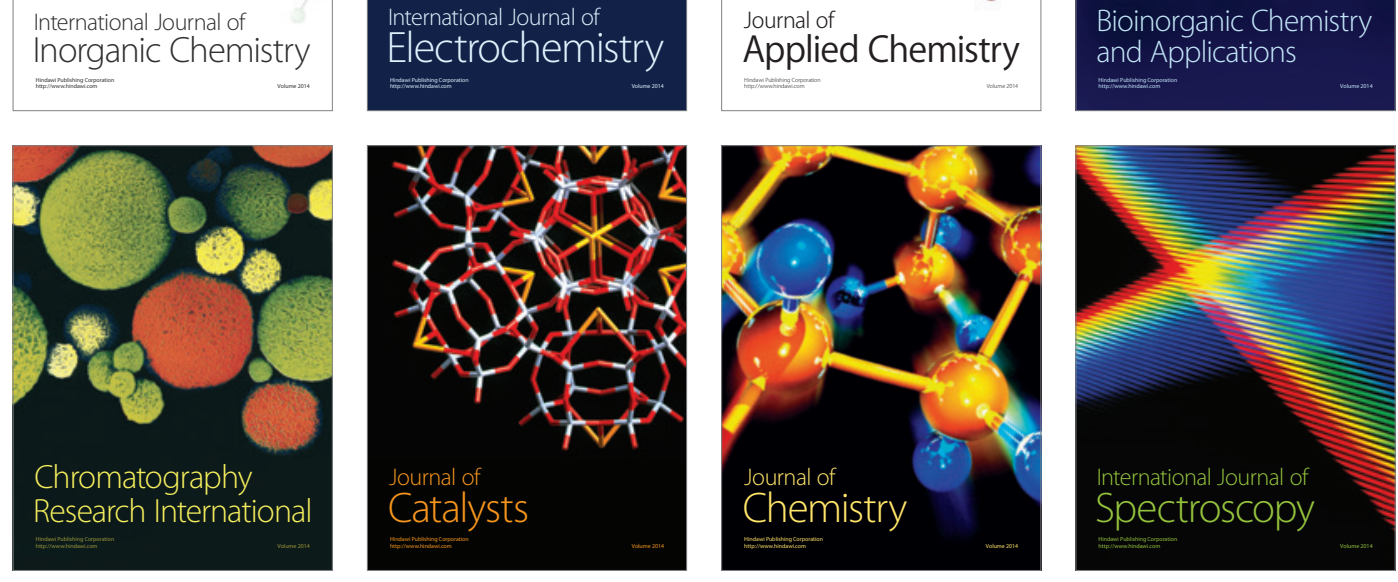